\title{
IDENTIFICATION OF Toxocara canis ANTIGENS BY WESTERN BLOT IN EXPERIMENTALLY INFECTED RABBITS
}

\author{
Olga Lucía MORALES(1), Myriam Consuelo LÓPEZ(1), Rubén Santiago NICHOLLS(1,2) \& Carlos AGUDELO(1)
}

\begin{abstract}
SUMMARY
Toxocariasis is a frequent helminthiasis that can cause visceral and ocular damage in humans specially in children. The identification of specific antigens of Toxocara canis is important in order to develop better diagnostic techniques. Ten rabbits were infected orally with a dose of 5000 Toxocara canis embryonated eggs. Rabbits were bled periodically and an ELISA assay was performed to determine levels of specific Toxocara IgG antibodies. ELISA detected antibodies at day 15 after infection. Western blot (WB) assay was performed using excretory/secretory antigens $(\mathrm{E} / \mathrm{S})$ of $T$. canis second stage larvae. Different antigen concentrations were evaluated: $150,200,250$ and $300 \mu \mathrm{g} / \mathrm{mL}$. The concentration of $250 \mu \mathrm{g} / \mathrm{mL}$ was retained for analysis. Rabbit sera were diluted 1:100. Secondary antibody was used at a dilution of 1:1000. Results of WB indicated that in the first month after infection specific antibodies against the $200 \mathrm{KDa}, 116 \mathrm{KDa}, 92 \mathrm{KDa}$ and $35 \mathrm{KDa}$ antigens were detected; antibodies against the $92 \mathrm{KDa}, 80 \mathrm{KDa}, 66 \mathrm{KDa}, 45 \mathrm{KDa}, 31 \mathrm{KDa}$ and $28 \mathrm{KDa}$ antigens appeared later. All positive sera in the ELISA test were also positive in WB. Two antigen bands, $92 \mathrm{KDa}$ and 35 $\mathrm{KDa}$, were identified since the beginning and throughout the course of infection. These antigens merit further evaluation as candidates for use in diagnosis.
\end{abstract}

KEY WORDS: Toxocara canis; Immunoblot; ELISA; Antibodies; Diagnosis.

\section{INTRODUCTION}

Toxocariasis is one of the parasitic diseases which constitute a public health problem in Colombia ${ }^{1}$. Its causal agent, the nematode helminth Toxocara canis, is an ascaridae frequently present in $\operatorname{dogs}^{20}$. Toxocariasis is a disease whose clinical manifestations are unspecific, characterized by larval migration to inner organs of humans and some animals ${ }^{10}$. In the absence of parasitological evidence of infection, immunological methods are required for its diagnosis ${ }^{10}$.

Currently, an ELISA technique is being used to detect IgG antibodies against the parasite ${ }^{9,22}$; this test uses an excretory / secretory antigen (E/ S) and provides a high sensitivity. The parasite proteins of this antigen which ellicit an immune response can be identified by immunological techniques. Therefore, this paper includes the detection of anti-Toxocara IgG antibodies in rabbit sera by an ELISA test and the characterization and identification of the antigenic components of $T$. canis present in the excretory / secretory antigen using the Western Blot technique.

\section{MATERIALS AND METHODS}

Experimental infection in rabbits: Twenty-seven puppies aged from one to three months were killed with a $5 \mathrm{ml}$ lethal intracardiac injection of a mixture of magnesium and potassium sulfate solutions. An incision on the abdominal wall was performed on every puppy, and the small intestine, where the adult parasites were located, was removed. The recovered worms were classified and the gravid uteri were extracted from the females. This material was digested for 30 minutes in acidpepsin solution (pepsin $1 \%, \mathrm{HCl} 0.1 \%$ ), washed and incubated in a $1 \%$ formalin solution at $28^{\circ} \mathrm{C}$. After 28 days, the embryonated eggs were hatched and one part of them was used for antigen preparation and the other for production of antibodies in rabbits.

Ten white New Zeland male rabbits of two months of age, were inoculated orally with 5000 infective eggs of $T$. canis. The infected rabbits, and three additional control rabbits, were bled periodically, every month, during seven months.

Preparation of the excretory/secretory larval antigen (E/S): Toxocara canis larvae were cultured in vitro according to the method described by DE SAVIGNY ${ }^{6}$. The culture medium used was Dulbeco's Modified Eagle's Medium (DEM) SIGMA ${ }^{\mathrm{R}}$ supplemented with antibiotics (penicillin and streptomycin) and sodium bicarbonate, $\mathrm{pH}$ 7.2. The concentration of larvae, determined following BADLEY et al. method $^{3}$, was of $10^{4} / 10 \mathrm{ml}$ of medium. The supernatant was divided into alliquots and stored at $-20^{\circ} \mathrm{C}$. One of these antigen lots was dialyzed and the

(1) Facultad de Medicina. Departamento de Salud Pública y Tropical. Instituto de Salud en el Trópico. Unidad de Parasitología, Universidad Nacional, Bogotá, Colombia. (2) Laboratorio de Parasitología, Instituto Nacional de Salud, Bogotá, Colombia.

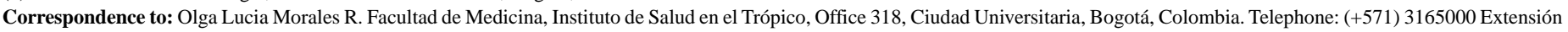
15033 y 15032. E-mail: lucia_morales@hotmail.com 
remaining were processed without dialysis.

IgG antibody detection in rabbitts by ELISA: The ELISA was performed following the guidelines by VOLLER et $a .^{22}$, and DE SAVIGNY et al. ${ }^{8}$. Antibodies against Toxocara canis antigens were determined in all the blood samples obtained periodically from the rabbits. Microplates of polystyrene (Inmunolon $\mathrm{I}^{\mathrm{R}}$ ) were covered with $100 \mu \mathrm{l}$ of a $1.0 \mu \mathrm{g}$ of protein / $\mathrm{ml} \mathrm{E/S} \mathrm{antigen} \mathrm{solution} \mathrm{in} \mathrm{carbonate} \mathrm{-} \mathrm{bicarbonate}$ buffer, $\mathrm{pH}$ 9.6. The plates were incubated for three hours at room temperature to allow for antigen adsorption. $100 \mu \mathrm{l}$ of diluted sera 1:800 in phosphate buffered saline (PBS) plus $0.5 \%$ Tween 20 solution and three wells were used per sample. Sera were incubated during 2 hours at room temperature. An alkaline phosphatase-anti-rabbit IgG conjugate was then added in a 1:1000 dilution and allowed to incubate overnight ( 18 hours) at $4^{\circ} \mathrm{C}$. The reaction was revealed by adding $100 \mu$ l of substrate, p-nitrophenyl phosphate in dietanolamine buffer $(1 \mathrm{mg} / \mathrm{ml})$, and stopped with $25 \mu \mathrm{l}$ of $3 \mathrm{~N} \mathrm{NaOH}$. The reading was performed at $405 \mathrm{~nm}$ and the cut-off value was established at 0.300 .

Western blot: Electrophoresis in poliacrylamide gels and immunoblot were performed following the method by MAGNAVAL et al. ${ }^{13}$. Poliacrylamide gels were prepared in a concentration of $10 \%$, with $2 \%$ sodium persulfate and Temed. For the estimation of molecular weights, a broad range molecular weight ladder standard (Bio-Rad ${ }^{\circledR}$ ) was used which included the following proteins: myosin, $200 \mathrm{KDa} ; \beta$ galactosidase, $116 \mathrm{KDa}$; phosphorilase $\mathrm{B}, 97 \mathrm{KDa}$; bovine serumalbumin, $66 \mathrm{KDa}$; ovum-albumin, $45 \mathrm{KDa}$; carbonic anhydrous, $31 \mathrm{KDa}$; soy trypsin inhibitor, $21 \mathrm{KDa}$; lysozime $14 \mathrm{KDa}$ and bovine pancreatic trypsin inhibitor $6.5 \mathrm{KDa}$. The antigen solution was mixed with Laemmli buffer $2 \mathrm{X}$ (Tris $0.125 \mathrm{M}$, SDS $5.1 \%$, glycerol $20 \%$, EDTA $0.01 \mathrm{M}, \beta$ mercaptoetanol $10 \%$, bromophenol blue $0.04 \%$ ) in a $1: 1 \mathrm{~V} / \mathrm{V}$ proportion and the mixture was allowed to reduce for 5 minutes. The running conditions were: 75 volts (V) for 15 minutes followed by $125 \mathrm{~V}$ during 80 minutes; in running buffer (Tris $0.025 \mathrm{M}$, Glycin 0.192M, methanol $2 \%$ ). Finally, the nitrocellulose membranes were stained with red Ponceau and washed with distilled water until the excess colouring was completely withdrawn.

The nitrocellulose membrane was blocked at $4{ }^{\circ} \mathrm{C}$ overnight with a blocking solution (Tris $0.020 \mathrm{M} \mathrm{pH} 7.4, \mathrm{NaCl} 0.500 \mathrm{M}$, Tween $200.1 \%$ and skimmed milk 5\%) to avoid nonspecific binding. Serum samples were diluted 1:400 in blocking solution, incubated with the nitrocellulose strips during $1 \mathrm{~h}$ at room temperature and washed with PBS/Tween 20 $0.1 \%$. The alkaline phosphatase-antirabbit IgG conjugate, diluted $1: 10,000$ in blocking solution, was added and allowed to incubate at room temperature for $1 \mathrm{~h}$. After five washes, the NBT/BCIP substrate was added (Nitro Blue Tetrazolium $0.3 \mathrm{mg} / \mathrm{ml}$, Bromine -4 Chlorine 3 Indol Phosphate $0.15 \mathrm{mg} / \mathrm{ml}$ ) in alkaline phosphatase (Tris $0.050 \mathrm{M}$, $\mathrm{MgCl}_{2} 0.004 \mathrm{M}, \mathrm{pH} 9.8$ ) activator solution; the reaction was then stopped by washing with distilled water.

\section{RESULTS}

Detection of anti - IgG antibodies in rabbit sera by ELISA: Each of the 15 serum samples obtained from bleeding periodically each rabbit during a six month period was processed for IgG antibodies by the ELISA test. Different positive and negative controls were used, thus verifying the reproducibility of the technique.
Antibody titers were first detected on day 15 after inoculation of the infective eggs. The cut-off point was 0.30 ; the mean of the titers of the control rabbits was 0.039 with a range between 0 and 0.154 . The infected rabbits presented high titers, between 0.344 and 1.889 . During the course of the infection, the positive titers increased rapidly between day 21 and day 58, remaining high and constant, with slight variations from then on. When averaging the obtained absorbances for each bleeding, from both the infected and control rabbits, the behavior of the humoral immune response to $T$. canis infection can be seen: at the beginning, titers tend to increase rapidly until day 60 and then they stabilize (Fig. 1).

Identification of specific T. canis proteins by Western blot: The immunoblot to detect anti-IgG antibodies was done for all the serum samples collected from rabbits during the six-month observation period. Thus, it was possible to assess the behavior of the immune response against the antigenic determinants of $T$. canis in every rabbit.

The antigenic determinants which react with antibodies vary during the course of infection: at the beginning four proteins of molecular weights $200 \mathrm{KDa}, 116 \mathrm{KDa}, 92 \mathrm{KDa}$ and $35 \mathrm{KDa}$ reacted strongly; at around day 30 seven characteristic bands of molecular weights $92 \mathrm{KDa}$, $80 \mathrm{KDa}, 66 \mathrm{KDa}, 45 \mathrm{KDa}, 35 \mathrm{KDa}, 31 \mathrm{KDa}$ and $28 \mathrm{KDa}$ are recognized; two bands that remain constant during all the course of infection were identified, the $92 \mathrm{KDa}$ and $35 \mathrm{KDa}$ proteins. This pattern remained constant for all the infected rabbits. On the other hand, sera from control rabbits (negative sera) did not present any reaction (Fig. 2).

\section{DISCUSSION}

Components of E/S T. canis antigen are identified by Western blot when they are confronted with sera of previously infected rabbits. A characteristic pattern of seven bands is observed, which can be grouped into one low molecular weight fraction $(28-45 \mathrm{KDa})$ and one high molecular weight fraction $(66-200 \mathrm{KDa})$. However, except for two proteins (the 92 and $35 \mathrm{KDa}$ proteins), not all of these antigens are recognized by sera during the whole course of the infection.

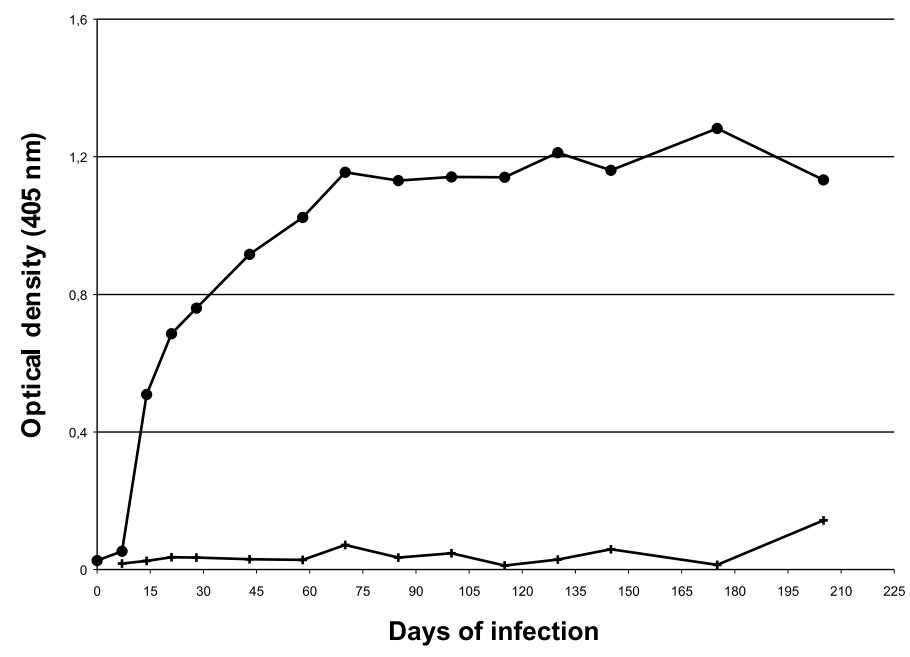

Fig. 1 - Course of the humoral immune response of rabbits against experimental Toxocara canis infection during a six month period. Average of optical densities: Infected rabbits $(\bullet)$; and non infected rabbits $(+)$. 


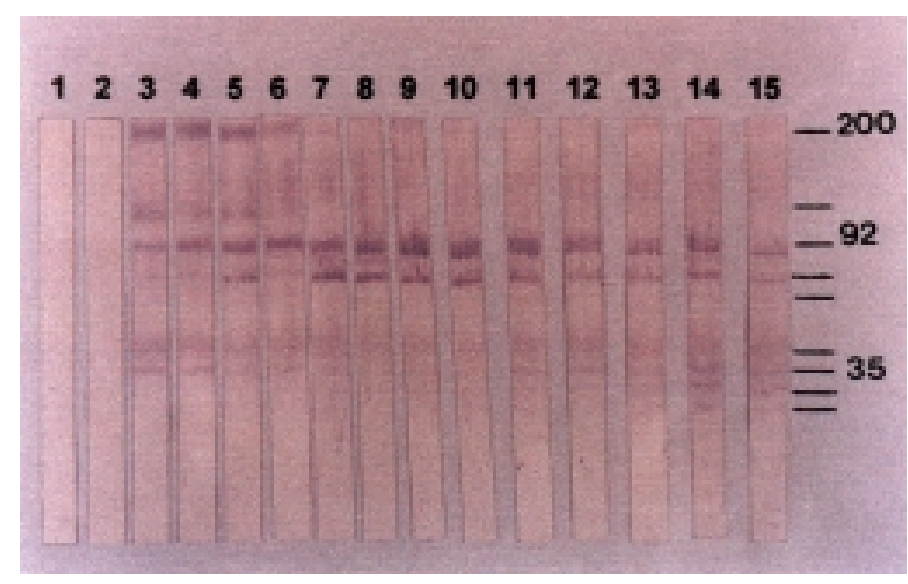

Fig. 2 - Antigenic components detected by antibodies of Toxocara canis of an experimentally infected rabbit throughout a 7 month follow-up. Lane 1: Day 0 (before experimental infection); Post-infection: Lane 2: day 7; Lane 3: day 14; Lane 4: day 21; Lane 5: day 28; Lane 6: day 43; Lane 7: day 58; Lane 8: day 70; Lane 9: day 85; Lane 10: day 100; Lane 11: day 115; Lane 12: day 130; Lane 13: day 145; Lane 14: day 175; Lane 15: day 205. The molecular weights of each band were estimated; two of them, the $92 \mathrm{KDa}$ and $35 \mathrm{KDa}$ bands, remained constant throughout the course of the infection.

AKAO et $a .^{2}{ }^{2}$ identified eight bands with sera of infected rabbits, while SPEISER \& GOTTSTEIN ${ }^{21}$ found 10 different antigenic components, common to two antigen preparations, and also noted crossreaction with filariae. BADLEY et al. ${ }^{3}$ detected 15 bands using sera obtained from infected rabbits and monkeys and from patients with visceral larva migrans (VLM) and ocular larva migrans (OLM). In a radio-iodine ES-Ag analysis MAIZELS et al. ${ }^{14,15}$, found five principal components, 32, 55, 70, 120 and $400 \mathrm{KDa}$ and established that the 400 KDa band corresponds to a polysaccharide fraction related to blood group antigens.

MAGNAVAL et al. ${ }^{13}$, classified into two groups the seven antigenic components detected, the high molecular fraction (132, 147 and 200 $\mathrm{KDa})$ and the low molecular fraction $(24,28,30$ and $35 \mathrm{KDa})$; they suggest that the high molecular weight fractions can account for crossreactivity while the low molecular weight fractions seem to be more specific of the genus Toxocara.

In our study, a correlation between the band pattern and the stage of infection can be observed: as infection progresses, the antigen-antibody reaction becomes visible on immunoblot. On the other hand, the concordance between the results in the ELISA test and the Western blot must be highlighted: positive or negative sera on the ELISA test yielded the same results in the Western blot. Similarly, MAGNAVAL et al. ${ }^{13}$ (1991) in the study about application of the Western blot for diagnosis of toxocariasis, demonstrated a correlation between these two immunological methods.

$\mathrm{JACOB}^{11}$ observed four bands with molecular weights between 29 and $210 \mathrm{KDa}$ and noted that the $66 \mathrm{KDa}$ band was also identified in some patients whose sera were used as negative controls. NUNES et $a l .{ }^{17}$, observed numerous bands in patients with signs of VLM, amongst which five principal components can be distinguished: (above $205 \mathrm{KDa}$, around $205 \mathrm{KDa}, 116$ - $97 \mathrm{KDa}, 55-50 \mathrm{KDa}$ and 35 - $29 \mathrm{KDa}$ ), and agree in that the low molecular weight fractions do not present any cross reactivity with other ascariid antigens.

During the antigen preparation process no protease inhibitors were used; however, the antigen obtained was of high quality and remained stable for a long period. ROBERTSON et al. ${ }^{19}$ in a study of proteolytic enzymes secreted by in vitro cultured $T$. canis larvae, state that some nematode species, including Toxocara, have protease activity in their excretion/secretion products, which under natural conditions are probably involved in the invasion and migration into their vertebrate hosts. Additionally, these in vitro secreted proteases are capable of degrading antigenic components causing loss of its reacting capacity in immunoassays. The optimal quality of the antigen, observed so far in this study, can probably be explained by the optimum conditions in the process of obtaining and storing; however, the appearance of protease activity in any moment cannot be excluded.

Amongst the new perspectives for the immunodiagnosis of toxocariasis, the development of new methodologies which make this diagnosis easier and more practical can be foreseen. YAMASAKI et $a l .{ }^{23}$, proposes the development of a highly specific recombinant $T$. canis antigen which yields greater specificity as compared to the conventional E/S antigen.

\section{RESUMO}

\section{Identificação de antígenos de Toxocara canis por Western blot em coelhos experimentalmente infectados}

O Toxocara canis é responsável por uma helmintíase freqüente, causando danos viscerais e oculares no ser humano, especialmente em crianças. A identificação de antígenos específicos de Toxocara canis é importante para se obter melhores técnicas de diagnóstico. Neste trabalho, dez coelhos foram infectados, por via oral, com um inóculo de 5000 ovos embrionados de T. canis. Periodicamente, foi coletado sangue dos coelhos para determinação dos níveis de anticorpos $\mathrm{IgG}$, pela técnica ELISA, que revelou anticorpos no $15^{\circ}$ dia após a infecção.

A técnica de Western blot foi realizada utilizando os antígenos excretores-secretores (E/S) com larvas de T. canis de segundo estádio. Foram avaliadas diferentes concentrações de antígeno: 150, 200, 250 e $300 \mu \mathrm{g} / \mathrm{mL}$.

No final, a concentração ótima de antígenos para análise foi $250 \mu \mathrm{g} /$ $\mathrm{mL}$. Cada soro foi diluído 1:100 e o anti IgG de coelho, ligado a fosfatase alcalina, fui utilizado a 1:10000. Os resultados do Western blot indicaram que no primeiro mês após a infecção apareceram anticorpos específicos contra os determinantes antigênicos $200 \mathrm{KDa}, 116 \mathrm{KDa}, 92 \mathrm{KDa}$ e 35 $\mathrm{KDa}$; os anticorpos contra $92 \mathrm{KDa}, 80 \mathrm{KDa}, 66 \mathrm{KDa}, 45 \mathrm{KDa}, 35 \mathrm{KDa}$ e $28 \mathrm{KDa}$ apareceram mais tarde. Todos os soros positivos pela técnica ELISA, também foram positivos pela de Western blot. Duas bandas estiveram presentes desde o começo da infecção. Estes antígenos justificam uma futura avaliação para uso no diagnóstico da Toxocaríase.

\section{ACKNOWLEDGMENTS}

The authors wish to express their thankfulness to the Facultad de Medicina, Universidad Nacional de Colombia, Bogotá, DC; to Dr. Carlos A. Agudelo, to Dr. Augusto Corredor and to Dr. Jorge Enrique Gómez; to the staff from Bioterio Central de la Universidad Nacional de 
Colombia; to Laboratorio de Parasitología, Instituto Nacional de Salud, Bogotá, and to Dr. Diana Díaz from Instituto de Inmunología, Hospital San Juan de Dios, Bogotá.

\section{REFERENCES}

1. AGUDELO, C.; VILlAREAL, E.; CÁCERES E. et al. - Human and dogs Toxocara canis infection in a poor neighborhood in Bogotá. Mem. Inst. Oswaldo Cruz, 85: $75-78,1990$

2. AKAO, N.; KONDO, K. \& YOSHIMURA, H. - Antigenic analysis of excretory-secretory products of $2^{\text {nd }}$ stage larvae of Toxocara canis and the antigen recognition in the course of infection. Jap. J. Parasit., 32: 551-558, 1983.

3. BADLEY, J.E.; GRIEVE, R.B.; BOWMAN, D.D.; GLICKMAN, L.T. \& ROCKEY, J.H. - Analysis of Toxocara canis larval secretory-excretory antigens: physicochemical characterization and antibody recognition. J. Parasit., 73: 593-600, 1987.

4. BOYCE, W.M.; BRANSTETTER, B.A. \& KAZACOS, K.R. - Comparative analysis of larval secretory-excretory antigens of Baylisascaris procyonis, Toxocara canis and Ascaris suum by Western blotting and enzyme immunoassay. Int. J. Parasit., 18: 109-113, 1988

5. CORREA, P.; GONZÁLEZ-MUGABURU, M.L. \& D'ALESSANDRO, A. - Primer caso colombiano de toxocariasis. Breve actualización del síndrome de la larva migrans visceral. Antioquia méd., 16: 489-497, 1966.

6. DE SAVIGNY, D.H. - In vitro maintenance of T. canis larvae and a simple method for the production of Toxocara ES antigen for use in serodiagnostic tests for visceral larva migrans. J. Parasit., 61: 781-782, 1975.

7. DE SAVIGNY, D.H. \& TIZARD, I.R. - Toxocaral larva migrans: the use of larval secretory antigens in haemagglutination and soluble antigen fluorescent antibody test. Trans. roy. Soc. trop. Med. Hyg., 71: 501-507, 1977.

8. DE SAVIGNY, D.H.; VOLLER, A. \& WOODRUFF, A.W. - Toxocariasis: serological diagnosis by enzyme immunoassay. J. clin. Path., 32: 284-288, 1979.

9. GLICKMAN, L.T.; SCHANTZ, P.; DOMBROSKE, R. \& CYPESS, R. - Evaluation of serodiagnostic tests for visceral larva migrans. Amer. J. trop. Med. Hyg., 27: 492498, 1978.

10. GLICKMAN, L.T. \& SCHANTZ, P.M. - Epidemiology and pathogenesis of zoonotic toxocariasis. Epidem. Rev., 3: 230-250, 1981.

11. JACOB, C.M.A. - Ánalise evolutiva dos parâmetros clínico-laboratorais da toxocaríase visceral na infância. São Paulo, 1995. (Tese de doutorado - Faculdade de Medicina da USP)
12. LOWRY, O.H.; ROSEBROUGH, N.J.; FARR, A.L. \& RANDALL, R.J. - Protein measurement with the Folin phenol reagent. J. biol. Chem., 193: 265-275, 1951.

13. MAGNAVAL, J.F.; FABRE, R.; MAURIÈRES, P.; CHARLET, J.P. \& DE LARRARD, B. - Application of the Western-blotting procedure for the immunodiagnosis of human toxocariasis. Parasit. Res., 77: 697-702, 1991.

14. MAIZELS, R.M.; DE SAVIGNY, D.H. \& OGILVIE, B.M. - Characterization of surface and excretory-secretory antigens of Toxocara canis infective larvae. Paras. Immunol., 6: $23-27,1984$.

15. MAIZELS, R.M.; KENNEDY, M.W.; MEGHJI, M.; ROBERTSON, B.D. \& SMITH, H.V. - Shared carbohydrate epitopes on distinct surface and secreted antigens on the parasitic nematode Toxocara canis. J. Immunol., 139: 207-214, 1987.

16. MEGHJI, M. \& MAIZELS, R.M. - Biochemical properties of larval excretory-secretory glycoproteins of the parasitic nematode Toxocara canis. Mol. Biochem. Parasit., 18: $155-170,1986$

17. NUNES, C.M.; TUNDISI, R.N.; GARCIA, J.F. et al. - Cross reactions between Toxocara canis and Ascaris suum in the diagnosis of visceral larva migrans by Western blotting technique. Rev. Inst. Med. trop. S. Paulo, 39: 253-256, 1997.

18. OAKS, J.A. \& KAYES, S.G. - Artificial hatching and culture of Toxocara canis second stage larvae. J. Parasit., 65: 969-970, 1979.

19. ROBERTSON, B.D.; BIANCO, A.T.; McKERROW, J.H. \& MAIZELS, R.M. -Toxocara canis proteolytic enzymes secreted by the infective larvae in vitro. Exp. Parasit., 69 30-36, 1989

20. SCHANTZ, P.M. \& GLICKMAN, L.T. - Ascaridios de perros y gatos un problema de Salud Pública y de Medicina Veterinaria. Bol. Ofic. sanit. panamer., 94: 571-586, 1983.

21. SPEISER, F. \& GOTTSTEIN, B. - A collaborative study on larval secretory-excretory antigens of Toxocara canis for the immunodiagnosis of human toxocariasis with ELISA. Acta trop. (Basel), 41: 361-372, 1984.

22. VOLLER, A.; BIDWELL, D.E. \& BARTLETT, A. - Enzyme immunoassays in diagnostic medicine: theory and practice. Bull. Wld. Hlth. Org., 53: 55-56, 1976.

23. YAMASAKI, H.; ARAKI, K.; LIM, P.K. et al. - Development of a highly specific recombinant Toxocara canis second-stage larva excretory-secretory antigen for immunodiagnosis of human toxocariasis. J. clin. Microbiol., 38: 1409-1413, 2000.

Received: 26 April 2001

Accepted: 10 May 2002 